UDC 669. 187. 046. 58 ESR

669. 14. $018.821: 669.15^{\prime} 26-194.55$

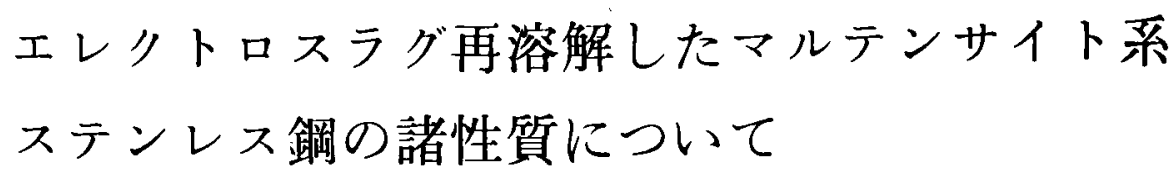

山口国男*・藤川峻 一*

\title{
Some Properties of Electroslag Remelted Martensite Type Stainless Steels
}

Kunio Yamaguchi and Shun-ichi Fujikawa

\section{Synopsis}

Some properties of martensitic stainless steel such as SUS 410 and $440 \mathrm{C}$ were investigated by electroslag remelting.

The special features of electroslag remelted material are as per described hereunder and the material was found to be by no means inferior to VAR material.

(1) After electroslag remelting the steel becomes such a pure steel with few nonmetallic inclusion.

(2) Elongation and reduction of area out of mechanical properties are improved.

(3) The hot workability is excellent.

(4) Good decarburizing composition can be obtained if moderate selection of each ingot size is made.

\section{1. 緒 言}

エレクトロスラグ再溶解法, (以下E S R 法と略 す）の歴史はかなり古く1937年に始まるか，わか国に 紹介され，試験的に溶解が開始されたのは10数年前で ある。その後真空アーク再溶解法（以下VAR法と略 す）の発羍で進展が一次頓座したが, 数年前からン連 を中心にして工業的規模の炣での溶解法および容解材 の特長が公表され，それ以後急速に発展をし，1971年 には世界最大の $160 \mathrm{t}$ 炉か西独で稼動”を始めた。い っぽ5わが国では1972年に10数基の炉が稼動してい る。

溶解法については，既に数多くの報告があり2゙ 4) 本誌5)にもすでに紹介されている。大同製鍴です沵川 工場に昭和 46 年 4 月に生産規模の多目的炉を設膡し,

昭和 47 年10月 1 日受付

*大同製鋼㑣涉川工場
テストならびに生産を続けており，その効果について 調查を進めてきた。今回は各種の特秼鋼の品質調查の 5ち、ステンレス鋼, 特にマルテンサイト系 Crステ ンレス鎆に適用した場合の材質的特長について報告す る。

ステンレス鋼は大別してフェライト采，マルテンサ イト系，オーステナイト系に分類されるが，従来から 高品質を要求され製造上問題のあるのは前 2 者であり

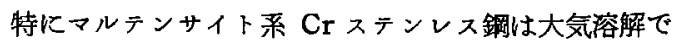
は品質のバラッキが大きく，タービンブレードなど高 い信頼性を要求される材料にはV AR 法が適用されて きた。

いっぽ5EＳR法が進歩するにつれて，既に諸誌に も発表されているように，VAR法に比べて経済性， 品質上の優位性などにより，VAR法に代わりつつあ り, 今後る転換のピッキは増加すると思われる。本調 査の一部は真空フーク再溶解材との比較行ってい る。 


\section{2. 装亚および使用鋼塊寸法}

装置は Photo. 1 に示す，大同一レイボルト・ヘラ ウス式 2 t E SR炸を用い，つぎの寸法の鋼塊を溶製， し試験に供した。

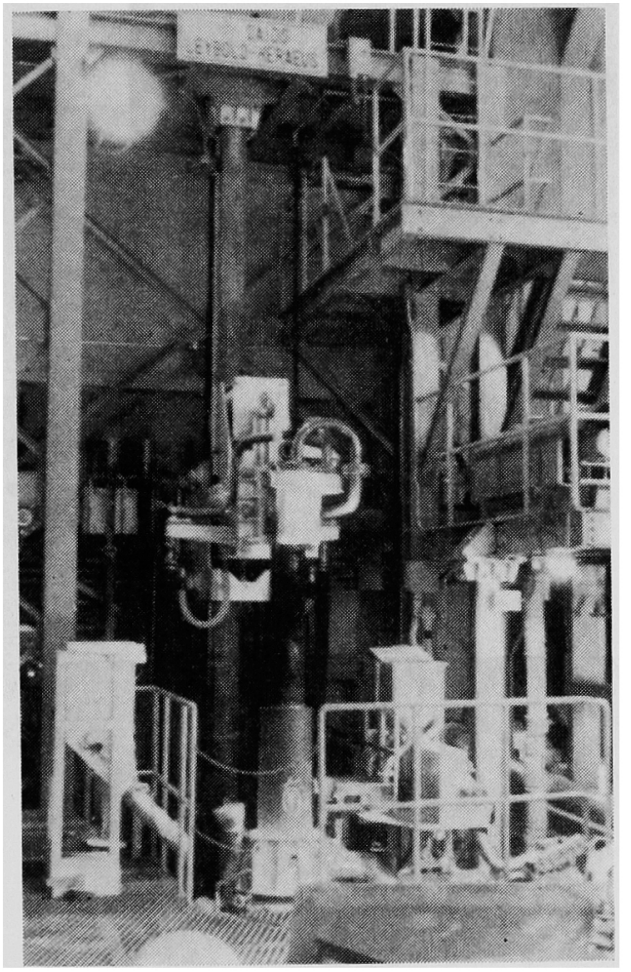

Photo.1. General view of $2 t$ ESR furnace.

$\begin{aligned} 280 \mathrm{~kg} \text { 鋼塊 } & 230 \mathrm{~mm} \phi \times 900 \mathrm{~mm} \ell \\ 700 \mathrm{~kg} \text { 鋼塊 } & 310 \mathrm{~mm} \phi \times 1200 \mathrm{~mm} \ell \\ 1800 \mathrm{~kg} \text { 鋼塊 } & 460 \mathrm{~mm} \phi \times 1450 \mathrm{~mm} \ell\end{aligned}$

鋼塊は Photo. 2に示す如く, 美麗な鋳肌で, 溶解 後直接次工程の鍛造あるいは压延に送ることができ る。しかし，VAR再溶解と異なり，マルテンサイト 系ステンレス鋼のE S R 鋼塊は変態応力による割れな どの問題があり次工程までの熱的取扱いについては十 分な注意を払 5必要がある。

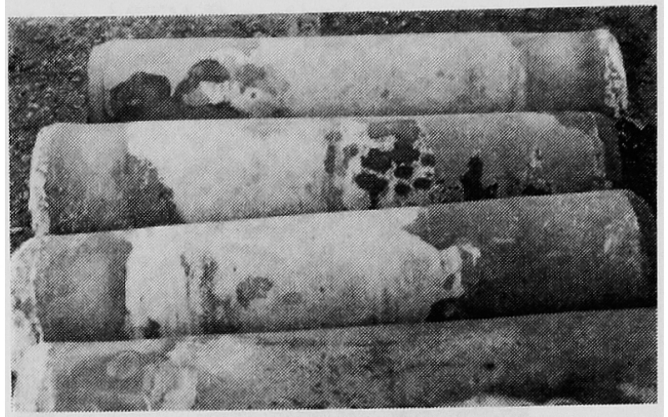

Photo. 2. Appearance of ESR ingot surface.

\section{3. エレクトロスラグ再溶解材の性質}

\section{$3.112 \% \operatorname{Cr}$ ステンレス鋼（S U S 410）}

Table 1 K供試材の化学成分を示す。

Table 1 でわかるよ5にESR材は脱硫効果によ り Sが低いことか特長であり，VAR材のMn および $\mathrm{Cu}$ のよ5に大きくハラッキを生じたり，大幅に変化 をする元素はない。

\subsection{1 マクロ組織}

Photo. 3 KE S R 材とVAR材のマクロ組織を示 す。マクロ組織を比較するとE S R 材はVAR材より 欠陷が少なく良好な組織である。E S R 材のマク口組 織の特長は脱硫効果と介在物の分散効果のため腐食ピ ットの少ない，耐食性の良好なことである。しかしい っぽ5 E S R材にはPhoto. 4 (a)，(b) に示すように 反ーフェライトの発生が他の溶解法に比し顕著であり, 十分ンーキングをし消滅させ，その後の熱間加工温度 にも注意して，再析出させないよ5にする必要があ る。

\section{1 .2 焼入焼もどし後のミク口組織}

Photo. 5 に $950^{\circ} \mathrm{C} \times 1 \mathrm{hrO}$ Q 後 $720^{\circ} \mathrm{C} \times 2 \mathrm{hrAC}$ したミクロ組織を示すが，偏析の少ない均一なソルバ イト組織であることがわかる。

\subsection{3 非金属介在物}

Fig. 1 に比較材（AF溶解材）とVAR材とE S R 村の非金属介在物の J I Sによる測定結果を示す。

図でわかるよ 5 に，A系はE S R 材の方が少なく， C系はVAR材の方が少ない。また，最近VAR材な どにはJ I S法でなく，ASTM一D法で測定される

Table 1. Chemical composition of $12 \% \mathrm{Cr}$ steel.

(\%)

\begin{tabular}{c|c|c|c|c|c|c|c|c}
\hline & $\mathrm{C}$ & $\mathrm{Si}$ & $\mathrm{Mn}$ & $\mathrm{P}$ & $\mathrm{S}$ & $\mathrm{Cu}$ & $\mathrm{Ni}$ & $\mathrm{Cr}$ \\
\hline $\begin{array}{c}\text { Pole ESR } \\
\text { before ESR }\end{array}$ & 0.13 & 0.38 & 0.69 & 0.026 & 0.009 & 0.08 & 0.41 & 11.62 \\
\hline $\begin{array}{c}\text { Ingot } \\
\text { after ESR }\end{array}$ & 0.13 & 0.36 & 0.67 & 0.025 & 0.005 & 0.08 & 0.42 & 11.58 \\
\hline
\end{tabular}




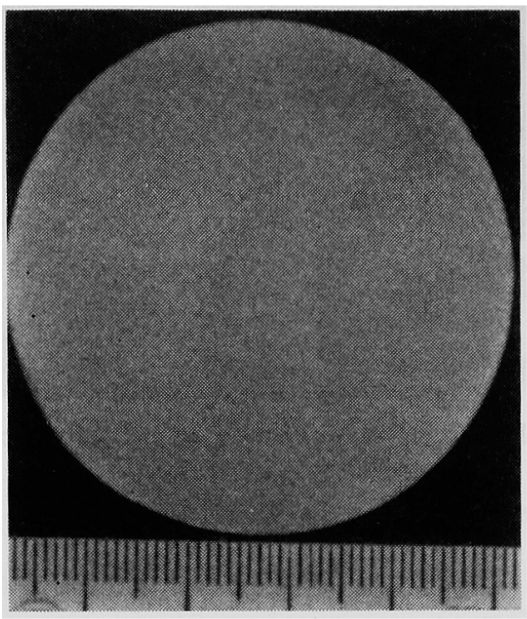

(a) Conventional steel

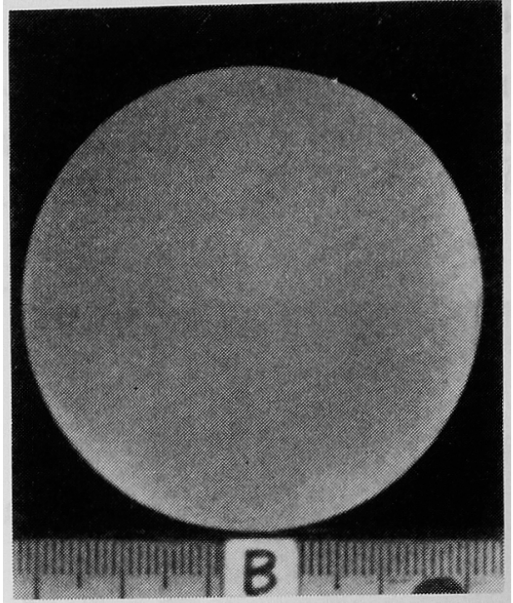

(b) ESR steel

Photo. 3. Macrostructure of $12 \% \mathrm{Cr}$ steel.

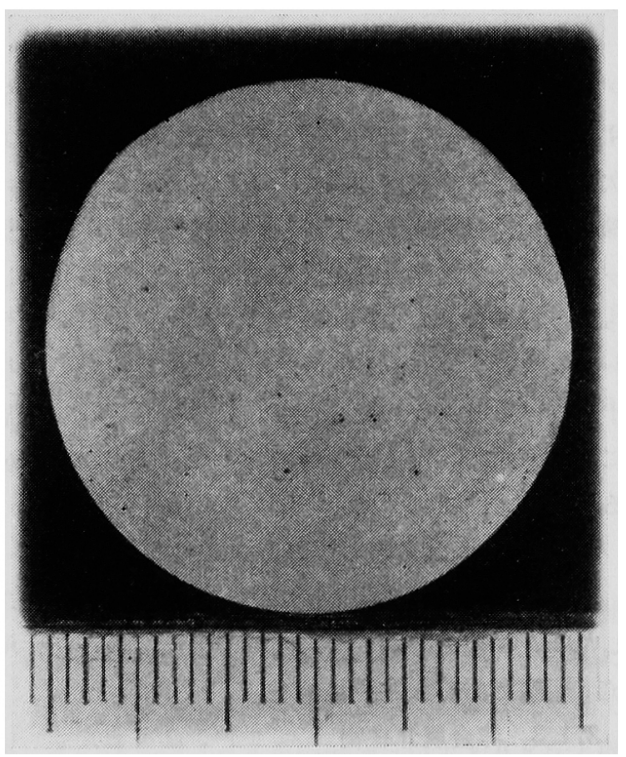

(a) Macrostructure of $12 \% \mathrm{Cr}$ steel with etch pit defect.

Photo. 4. Macrostructure of $12 \% \mathrm{Cr}$ steel with etch pit defect.
結果が多く，Table 2 に同法での測定結果を示してお く。比較材は参考のためA S T M-D法で測定した結 果である。

\section{1 .4 地きず}

$55 \mathrm{~mm} \phi$ 压延材の监光磁探による 3 段地きず椧查の 結果を Table 3 に示す。また, 地きず検查結果の各 段の地きず総長のヒストグラムを Fig. 2 に示す。 $\mathrm{E}$

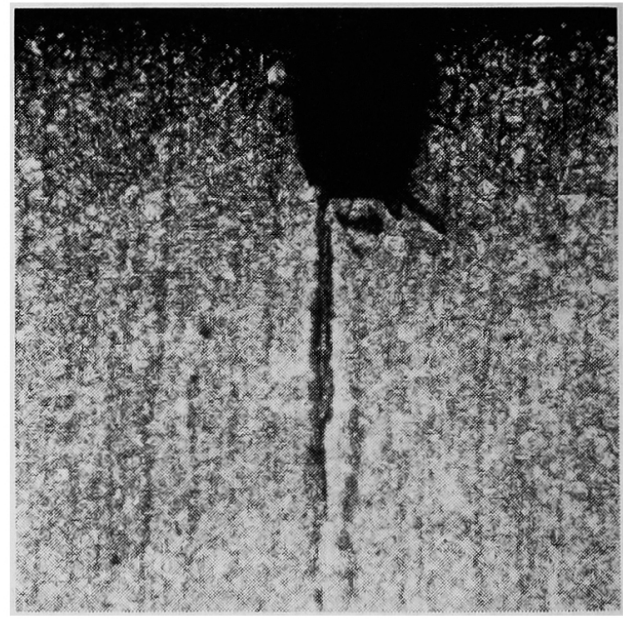

(b) Microstructure of etch pit part.
S R 材はVAR材に比較して地きずの発生率ですぐれ ていることがわかる。これはすで諸誌の゙に発表され ているよ 5 に介在物の微細化效果によるものと思われ る。

\section{1 .5 撵械的性質}

Fig. 3 に比較材, VAR材, ESR材の機㖅的性 質を示す。同一ナャージでないため若干の相違はある 
Table 2. Non-metallic inclusions by ASTM-D method.

\begin{tabular}{c|c|c|c|c|c|c|c|c}
\hline \multirow{2}{*}{$\begin{array}{c}\text { Method Type } \\
\text { of production }\end{array}$} & \multicolumn{2}{|c|}{$\mathrm{A}$} & \multicolumn{2}{|c|}{$\mathrm{B}$} & \multicolumn{2}{|c|}{$\mathrm{C}$} & \multicolumn{2}{|c}{$\mathrm{D}$} \\
\cline { 2 - 9 } & $\mathrm{T}$ & $\mathrm{H}$ & $\mathrm{T}$ & $\mathrm{H}$ & $\mathrm{T}$ & $\mathrm{H}$ & $\mathrm{T}$ & $\mathrm{H}$ \\
\hline Conventional & 2.5 & 1.0 & 2.0 & 1.0 & 0 & 0 & 2.0 & 1.5 \\
\hline V A R & 1.5 & 0 & 0 & 0 & 0 & 0 & 1.0 & 1.0 \\
\hline E S R & 1.0 & 0 & 1.5 & 0 & 0 & 0 & 1.5 & 1.0 \\
\hline
\end{tabular}

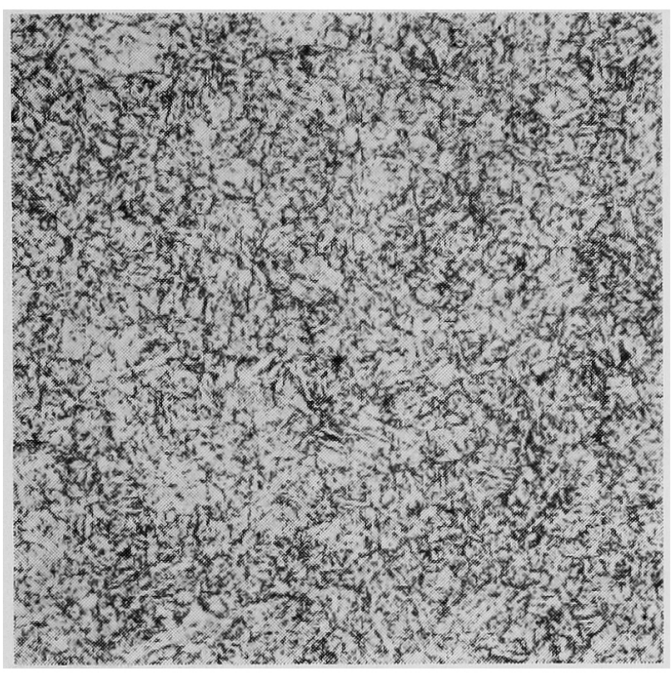

Photo. 5. Microstructure of tempered $12 \% \mathrm{Cr}$ steel.

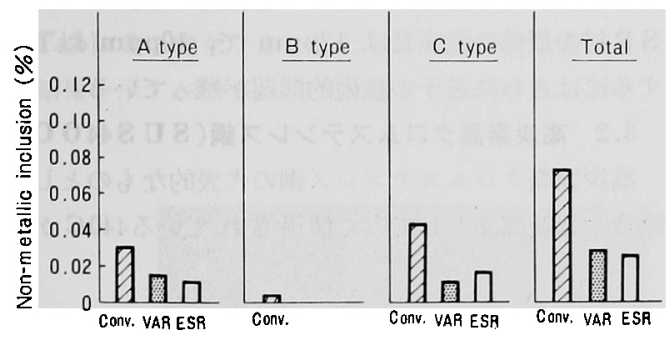

Fig.1. Diagram of inclusion contamination of $12 \%$ Cr steel.

か，EＳR材の特長はV AR材の場合と同様で伸び， 皎り, 衝撃值の改善勃果が認められる。今回は緃方向 と横方向の機械的性質の差一すなわち異方性について は調查をしていないか，構造用鋼で調查した結果てで は他の溶解法に比較して少なく，EＳR法の大きなみ リットの一つであることが確認できた。

Fig. 4 は熱間における機械的性質のデータで
Table 3. Results by sand mark inspection.

\begin{tabular}{|c|c|c|c|c|c|c|c|c|c|}
\hline \multirow{2}{*}{$\begin{array}{c}\text { Method } \\
\text { of } \\
\text { production }\end{array}$} & \multicolumn{2}{|c|}{ Grade No. } & 0.5 & 1 & 2 & 2 & 3 & 3 & $4 u p$ \\
\hline & & & $\begin{array}{l}0.1 \\
\sim 0.5\end{array}$ & $\begin{array}{l}0.5 \\
-1.0\end{array}$ & $\begin{array}{l}1.0 \\
-1.5\end{array}$ & $\begin{array}{l}1.5 \\
-2.0\end{array}$ & $\begin{array}{l}2.0 \\
\sim 2.5\end{array}$ & $\begin{array}{l}2.5 \\
\sim 3.0\end{array}$ & $>3$ \\
\hline \multirow{3}{*}{$\begin{array}{c}\text { Conventional } \\
\text { (A.F) }\end{array}$} & 1 & $79 \times 63.6$ & 2 & 1 & 0 & 0 & 1 & 0 & 0 \\
\hline & 2 & $56 \times 63.6$ & 2 & 1 & 1 & 0 & 0 & 0 & 0 \\
\hline & 3 & $42 \times 63.6$ & 1 & 1 & 2 & 0 & 0 & 0 & 0 \\
\hline \multirow{3}{*}{ ESR } & 1 & $49.9 \times 63.6$ & 0 & 0 & 0 & 0 & 0 & 0 & 0 \\
\hline & 2 & $35.3 \times 63.6$ & 0 & 0 & 0 & 0 & 0 & 0 & 0 \\
\hline & 3 & $265 \times 63.6$ & 0 & 0 & 0 & 0 & 0 & 0 & 0 \\
\hline
\end{tabular}

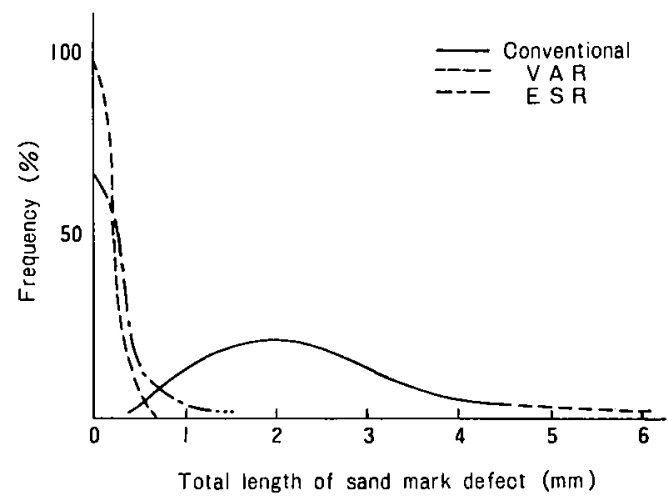

Fig. 2. Frequency diagrams of total sand mark length.

VAR材と同等の傾向を示している。

以上一般的な性質について報告したか，EＳR材の 特長である非金属介在物の減少の基礎となる脱硫, 脱 酸効果について付記してみた。

\subsubsection{E S Rによる脱硫，脱酸効果}

(1) 脱硫勃果

Fig. 5 に母材のS\%と溶解後のS\%の関保を示す が，既に報告されているよ5に母材 $\mathrm{S} \% の$ 高いすのほ ど脱硫效果か顕著である。特にステンレス鐝の場合 $\mathrm{CaO}$ の多い脱硫スラグを使用できる点も脱硫に効果 的である。Fig. 6 にはJ I S法に上る A系介在物の 面積率のヒストグラムを示すが，傾向として大きな介 在物が減少していることがわかる。 


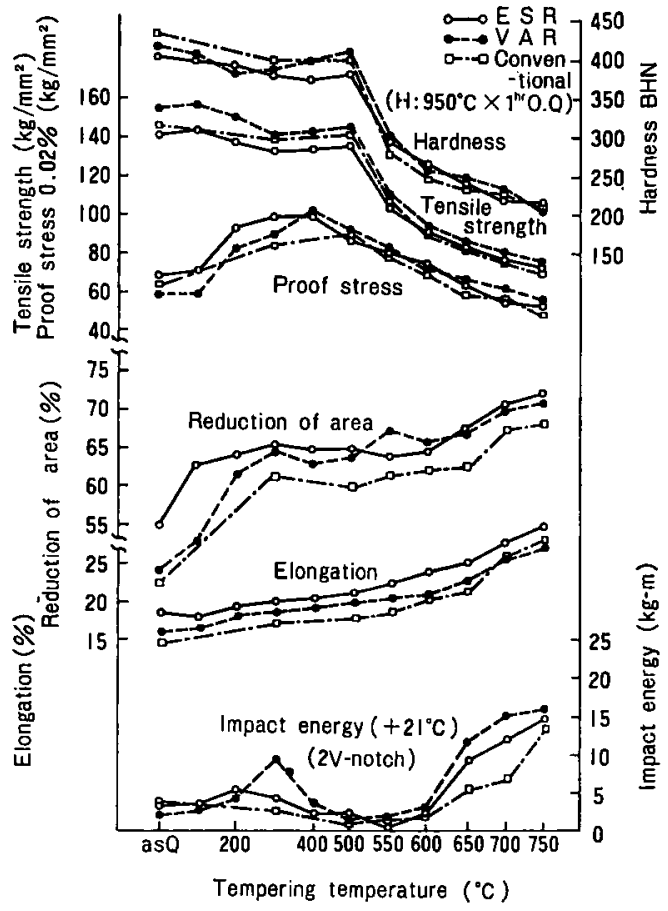

Fig. 3. Mechanical properties of $12 \% \mathrm{Cr}$ steel.

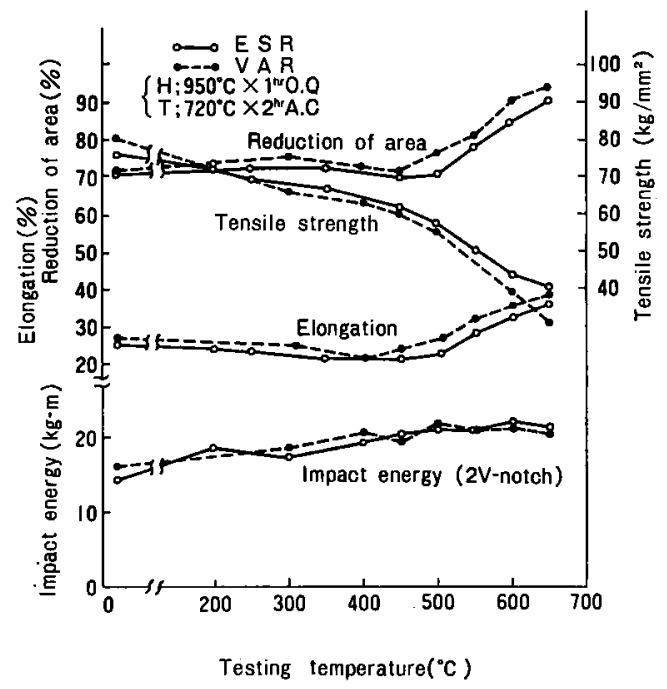

Fig. 4. Mechanical properties of $12 \% \mathrm{Cr}$ steel at elevated temperature.

\section{(2) 脱酸効果}

E S Rによる脱酸効果については種々データがあ る。一般的にはVAR 法より脱酸效果が劣るといわれ ている。今回の調查の結果すVAR材に比し酸素レベ ルは高かったが，これは溶解法に左右されるところが

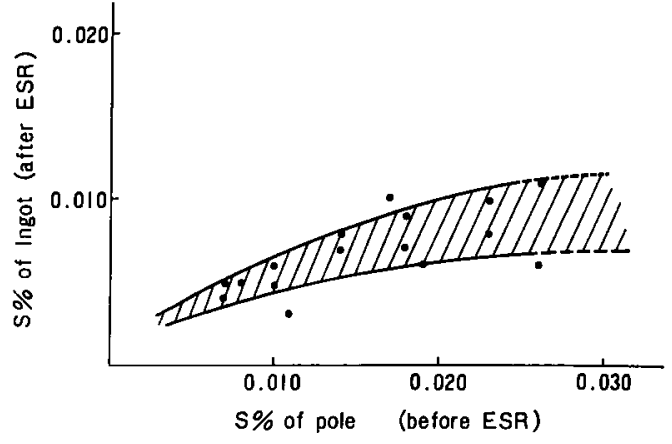

Fig. 5. Behaviour of sulfur after electroslag remelting.

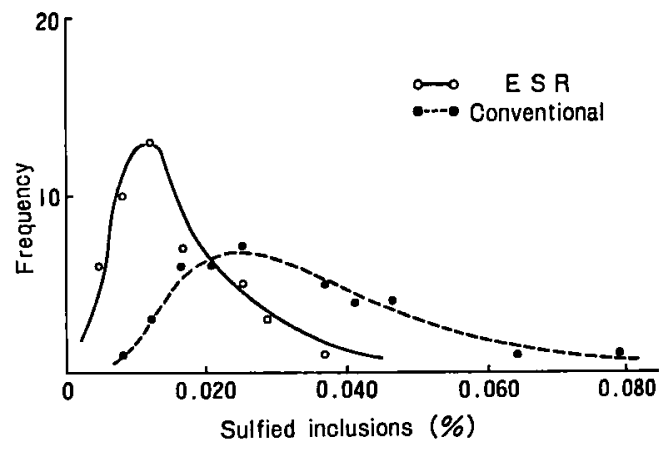

Fig.6. Frequency diagrams of sulfide contamination of $12 \% \mathrm{Cr}$ steel.

多い。その後脱酸に留意して溶解を行なえば50\%前後 の脱酸効果があることがわかった。 Fig. 7 にその一 例を示す。な技他の鋼種む含めて今までに得られた $\mathrm{E}$ S R 材の最低の酸素量は 12ppm で，10ppm 以下に するにはさらに若干の技術的問題か残っている。

\section{2 高炭䅇高クロムステンレス銅（ＵＵＳ440 C)}

高炭素高クロムステンレス鍮の代表的なすのとして 耐食耐摩耗部品として広く使用されている440Cがあ

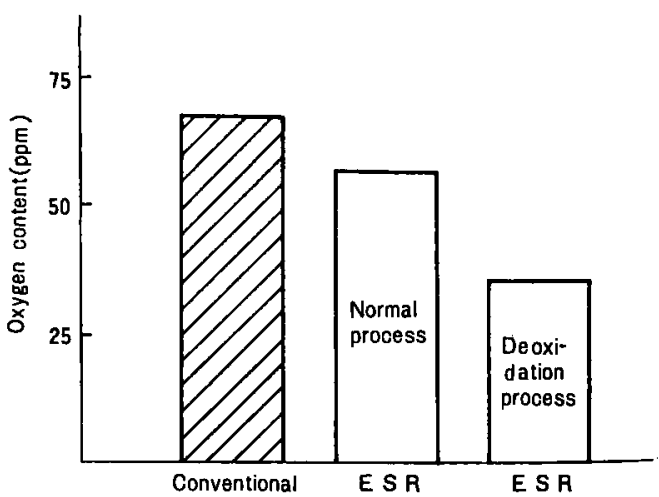

Fig.7. Oxygen content in $12 \%$ Cr steel. 
Table 4. Chemical compositions of $440 \mathrm{C}$ steel.

\begin{tabular}{c|c|c|c|c|c|c|c|c|c}
\hline & $\mathrm{C}$ & $\mathrm{Si}$ & $\mathrm{Mn}$ & $\mathrm{P}$ & $\mathrm{S}$ & $\mathrm{Cu}$ & $\mathrm{Ni}$ & $\mathrm{Cr}$ & $\mathrm{Mo}$ \\
\hline $\begin{array}{c}\text { Pole } \\
\text { before ESR }\end{array}$ & 0.98 & 0.44 & 0.57 & 0.029 & 0.017 & 0.08 & 0.24 & 16.90 & 0.39 \\
\hline $\begin{array}{c}\text { Ingot } \\
\text { after ESR }\end{array}$ & 1.01 & 0.41 & 0.56 & 0.027 & 0.009 & 0.08 & 0.24 & 16.45 & 0.38 \\
\hline
\end{tabular}

Table 5. Mechanical properties of $440 \mathrm{C}$ steel.

\begin{tabular}{c|c|c|c|c|c}
\hline & $\begin{array}{r}\text { Yield strength } \\
\mathrm{kg} / \mathrm{mm}^{2}\end{array}$ & $\begin{array}{c}\text { Tensile st- } \\
\text { rength } \mathrm{kg} / \mathrm{mm}^{2}\end{array}$ & $\begin{array}{c}\text { Elongation } \\
\%\end{array}$ & $\begin{array}{c}\text { Reduction of } \\
\text { area } \%\end{array}$ & $\begin{array}{c}\text { Hardness } \\
\mathrm{H}_{\mathrm{R}} \mathrm{B}\end{array}$ \\
\hline Conventional & 38.3 & 77.4 & 6.5 & 9.0 & 94.3 \\
\hline $\mathrm{E} \mathrm{S} \mathrm{R}$ & 40.3 & 83.8 & 18.6 & 30.2 & 99.6 \\
\hline
\end{tabular}

as full annealed

る。特に 440 Cは熱間, 冷閒の加工性が劣り, 従来か ら製造上のトラブルが䋓えず，量産化し難い鋼の一つ であった。Table 4 亿供試材のE S R 前後の成分の一 例を示す。前にも述べたよ 5 に，ESRによる脱硫效 果が認められる。

\section{2 .1 熱間加工性}

Fig. 8 は比較材（I F溶解材）と E S R 材の熱間 ねじり試験の結果を示す。試験片はいずれる $25 \mathrm{~mm} \phi$ の鍛伸材から切出したものであるが，元来加工性の悪 い材料であるため抢回值も低く，比較材との差もわず かであるが，実際の製造上はこの差か非常に大きく作 用し，特に歩留りにおいては10\%以上の差となって表 われる。

\section{2 .2 機械的性算}

Table 5に焼きなまししたすのの比較材とE S R 材 の結果を示すが伸び，絞りが著しく改善されており，

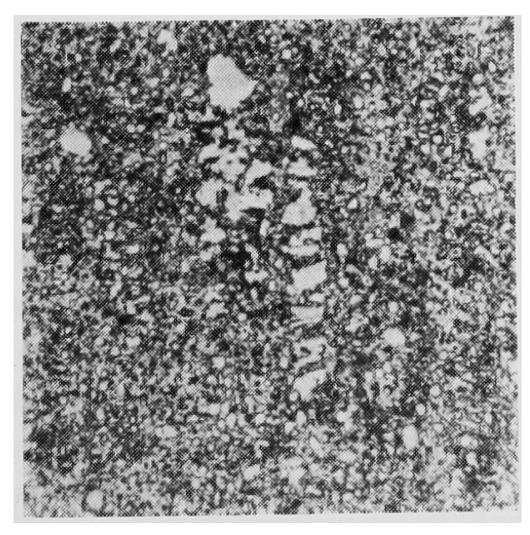

Conventional steel $(8 \mathrm{~mm} \phi)$

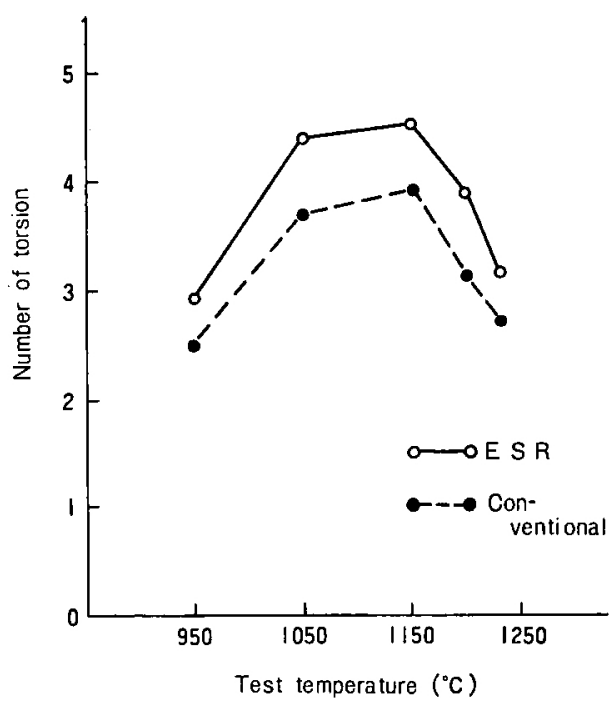

Fig. 8. Result in hot twist test of $440 \mathrm{C}$ steel.

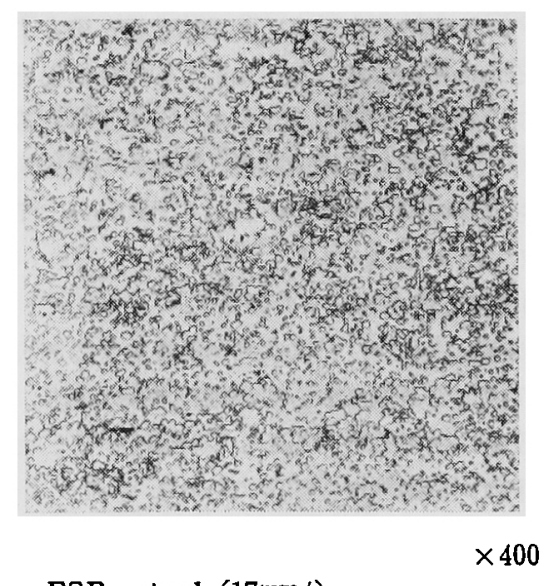

ESR steel (17mm $\phi)$

Photo. 6. Microstructure of SUS $440 \mathrm{C}$ steel. 


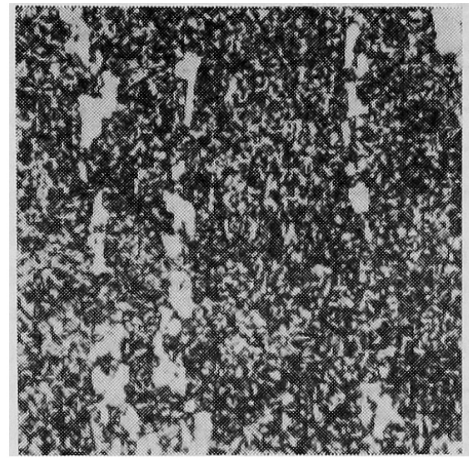

Photo. 7. Microstructure of slighly segregation SUS $440 \mathrm{C}$ steel.

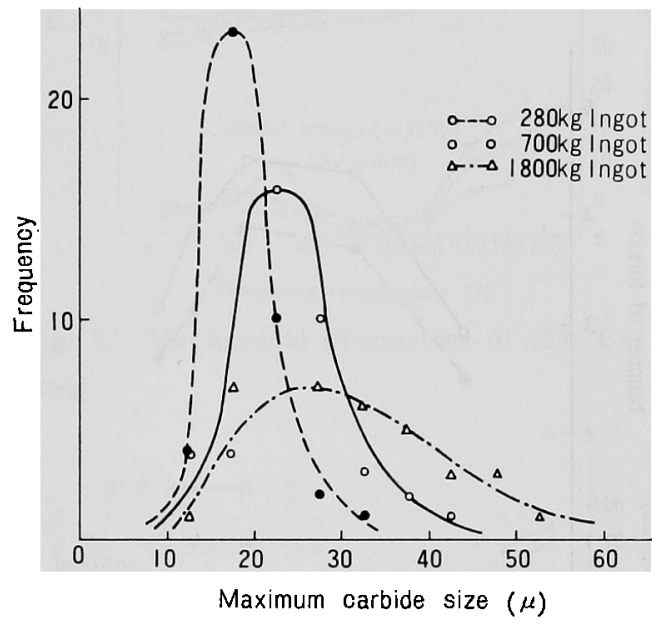

Fig. 9. Effect of ingot size on distribution of maximum carbide.

線材を冷間加工するには，EＳＲ材の方がいかに優位 であるかがわからら。

\subsection{3 ミクロ組織}

Photo. 6 にその一例を示す。共晶炭化物が残存す る組織であるために鍛鍊比（加工比）との関倸がある が，E S R材の場合，鍛鍊の少ないものであ良好な組 織となる。特に低倍率での検鏡結果，炭化物の㠜集組 織; すなわち偏折の少ないことがわかる。Photo. 7 は鍛錬比 6 の場合の組織である。

\subsection{4 鋼塊徍と炭化物分布の関係}

E S Rの効果は炭化物; 特に共晶組織を有する高炭 素工具鋼，高速度工具鋼に批いて微細化效果があり， 工具寿命の改善に効果的8)であるといわれている。 た，その効果は大型鋼塊ほど顕著であるとされてい る。

今回調查した $280 \mathrm{~kg}$ から $1800 \mathrm{~kg}$ までの鋼塊からか なり鍛錬比のきいた $13 \mathrm{~mm} \phi$ から $20 \mathrm{~mm} \phi$ までの最大
炭化物の頻度を Fig. 9 に示す。図から明らかなよう に鋼塊寸法の差が認められる。また分布の状態も異な ることがわかる。従ってESRといえどす炭化物の微 細な組織を得るには径の小さい鋼塊で啇正な溶解を行 なら必要がある。

\section{4. をとめ}

E S R材の諸性質についての調查結果は従来報告さ れている効果と同一であり，VAR材と比較して何ら 䞯色がなく，経済性などの観点から見ればE S Rの方 が優位であることが確認できた。さらに実用上の諸性 質を調查中であるか，E S R 材の特長ををとめると下 記のよ5になる。

（1）非金属介在物; 特に A系の少ない清浄鋼が得られ る。

（2）偏析などの欠宿の少ない良好なマクロ組織が得ら れる。

（3）熱間加工性がすぐれている。

(4) 伸び，校りなど靬性が改善される。

（5）適当な鋼塊寸法を選べ゙良好な炭化物組織が得ら れる。

以上，今回はマルテンサイト系ステンレス鋼のE S R材の諸性質について調查した結果をまとめたか， E S Rそのものは未完成な技術であり，VAR法より溶 解バラメータが多く日)鋼種扑よび客先の要求品質によ ってはその条件選定が難しい。従って条件の選定を鿁 まれば欠宿の発生も見られる。今後さらにE S Rの技 術的な研究と溶解法の安定が急務であろう。

（文献）

1) A. Choudhury, R. Jauch; 3 rd ESR Symposium, 1971-6

2) B.E. Paton et al.; Iron \& Steel, 34 (1961) 3, 102 104

3) W. Holzgruber et al.; Stahl u. Eisen, 88 (1968) $12,638 \sim 648$

4) Yu. V.Latash, B. I. Medovar; Electroslag Melting, 1970

5）加藤; 電気製䤡， 41 (1970） $4 ， 302 \sim 313$

6) M, Wahlster et al.; Stahl u. Eisen, 88 (1968) 23, 1193 1202

7）大同製鎙；第46回特殊鎆部会資料

8) I. Petrman; $3 \mathrm{rd}$ ESR Symposium, 1971-6

9) H.J. Mueller-Aue; Proceedings of the Vacuum Metallurgy Conference 1971 